\title{
Epidemiological Behavior of HIV Infection in Adolescents. Cuba, 1987-2018
}

\author{
Alba Cortés Alfaro ${ }^{1 *}$, Rosaida Ochoa Soto ${ }^{2}$, María Isela Latero Abreu ${ }^{3}$, Ramón Suárez Medina $^{4}$ \\ and Jose Joaquín Joanes Fiol ${ }^{5}$ \\ ${ }^{1}$ Department School Health, National Institute of Hygiene, Epidemiology and Microbiology (INHEM), Cuba
}

${ }^{2}$ Master's in public health, $2^{\text {nd }}$ Grade Specialist in Psychiatry, Researcher and Assistant Professor, Health Promotion and Disease Prevention Unit, Cuba

${ }^{3}$ National Directorate of Epidemiology, Department of STI-HIV / AIDS. MINSAP, $1^{\text {st }}$ Degree Specialist in Epidemiology, Cuba

${ }^{4}$ Assistant Professor and Researcher, $1{ }^{\text {st }}$ Degree Specialist in Biostatistics, Cuba

${ }^{5}$ National Directorate of Epidemiology, Department of STI-HIV / AIDS. MINS, $1^{\text {st }}$ Degree Specialist in Epidemiology, Cuba

*Corresponding author: Alba Cortés Alfaro, Department School Health, National Institute of Hygiene, Epidemiology and

Microbiology (INHEM), Cuba

\begin{abstract}
ARTICLE INFO
Received: 幽 August 15, 2019

Published: August 26, 2019

Citation: Alba Cortés A, Rosaida Ochoa S, María Isela Latero A, Ramón Suárez M, Jose Joaquín Joanes F. Epidemiological Behavior of HIV Infection in Adolescents. Cuba, 1987-2018. Biomed J Sci \& Tech Res 20(5)-2019. BJSTR. MS.ID.003517.
\end{abstract}

Keywords: HIV; Epidemiology; Geographic Distribution; Adolescence

\begin{abstract}
HIV / AIDS infection is considered a public health problem worldwide and Cuba is no stranger to this phenomenon and work continues to stop the progress of the epidemic in the country. Adolescence, a period of turbulence with affective ambivalence, which together with the early onset of sexual intercourse and its unprotected practice make them a vulnerable stage to HIV / AIDS infection. Objective: to characterize the epidemiological behavior of HIV in adolescence (10 to 19 years old) from 1987 (report of the first cases in Cuba at these ages) to December 2018. Method: retrospective descriptive study of the total cases of adolescents diagnosed as HIV in Cuba in the period from January 1987 to December 2018. The information was obtained from the registry of sexually transmitted infections (STIs) and HIV / AIDS from the National Directorate of Epidemiology of the Ministry of Public Health (MINSAP). The universe was made up of 2090 cases diagnosed with male predominance for 63.3 with low percentages in the ages of 10 to 14 years with 38 cases $(1.8 \%)$ throughout the epidemic, 1,434 (68.6) remain asymptomatic and 656 cases have developed AIDS for $31.4 \%$. Of those killed by AIDS, only $14.5 \%$ of the 303 cases have died from this cause. As for its location, the highest percentages are found in Outpatient Care. Conclusions: Male predominance, the source of transmission was primarily homosexual. The highest percentage of those diagnosed with HIV are in the condition of Outpatient Care.
\end{abstract}

\section{Introduction}

According to new data, HIV continues to be one of the biggest problems for global public health, which has claimed more than 35 million lives. In 2016, one million people died worldwide due to causes related to this virus and at the end of 2016 there were approximately 36.7 million people infected with HIV in the world, and in that year there were 1.8 million new infections .one The African region also remains the most affected, and almost twothirds of the new HIV infections in the world are recorded [1]. Between 2000 and 2016, the number of new HIV infections was reduced by $39 \%$ and deaths associated with the virus decreased by a third due to the enormous efforts made in the framework of national programs to combat HIV, with the civil society assistance and a set of development partners [2]. Worldwide, in 2014 there were 220,000 new HIV infections among adolescents, of which more than $60 \%$ were girls and women, a figure that is higher in sub-Saharan Africa. But nevertheless; Despite these facts, teenagers are less likely to be screened than adults [3]. It is estimated that one seventh of new HIV infections worldwide occur during adolescence and often people affected do not know their problem and it is stated that "adolescents face difficult and often confusing social and emotional pressures. , while passing from children to adults, so they need medical services for HIV prevention adapted to their situation, 
"according to the WHO, while expressing that this population group is less likely to be tested than adults and They need more help to monitor their health and follow an antiretroviral treatment with commitment.

In this sense, it is pointed out in surveys carried out by this organization in 2011 and 2012, that adolescents worldwide expressed their concerns and the difficulties they face; These include the lack of sufficient access to HIV testing, counseling services and treatment [4,5]. The World Health Organization (WHO) reports that more than two million adolescents between 10 and 19 years of age live with the human immunodeficiency virus (HIV), figures that show that the number of infected increased by one third in the last decade, a phenomenon that is due to the lack of education programs on the subject aimed at this age group since they do not receive the attention or support they need and sometimes do not even know their status as infected, so millions more of adolescents They are at risk of infection. The entity proposed a guide to address this situation based on advice among which are recommendations to governments to review their laws to facilitate young people to obtain HIV tests without the need of their parents' consent as well as the importance of creating health services in improving the quality of care and social support for the infected [6]. The international community has made a commitment to end the AIDS epidemic as a threat to public health by 2030 [7].

Adolescence, a period of turbulence with affective ambivalence, which together with the early onset of sexual intercourse and its unprotected practice make them a vulnerable stage to HIV infection. Adolescence, a period of life that passes between 10 and 19 years is a crucial stage, because there are profound physical, psychological and social changes. It is a stage in which they are exposed to risk factors and behaviors that are respectively the elements that increase the probability of triggering or associated with the unleashing of some undesirable event, getting sick or dying and repeated actions outside certain limits, which can divert or compromise their normal psychosocial development, with detrimental repercussions for current or future life [8-11]. The lack of information to protect themselves from STIs / HIV / AIDS and indiscriminate and unprotected sexual activity are more relevant risk factors and behaviors for the acquisition of these infections, and difficult to understand because they have a long incubation period and Do not see in immediate risky behavior obvious overt consequences. In addition, many adolescents do not know what is meant by risky sexual behavior and even knowing the risk, many believe that they themselves are invulnerable.

The United Nations Children's Fund (UNICEF) calls for increased investment in all aspects of adolescent life and well-being and even in its struggle for survival by referring that every year 1, 4 million adolescents die from traffic accidents, complications in childbirth, suicide, AIDS, violence and other causes [12]. and warns that new HIV transmissions in adolescents could increase by 60\% in 203013. The need to identify the epidemiological characteristics of HIV infection, among the total of adolescents reported as HIV-positive since the beginning of the epidemic for these ages in the period between January 1987 and December 2018 in Cuba, motivated the realization of the present study.

\section{Methods}

A retrospective descriptive study of the total cases of adolescents diagnosed as HIV in Cuba was carried out in the period from January 1987 to December 2018. The universe consisted of the 2090 cases reported in the country. The information was obtained from the registry of sexually transmitted infections (STIs) and HIV / AIDS from the National Directorate of Epidemiology of the Ministry of Public Health (MINSAP). The variables analyzed were sex, age, skin color, year of occurrence, forms of transmission, stage of infection and province of residence. The processing was done using the statistical package SPSS version 15.0, obtaining absolute frequencies and percentages. The masculinity index was calculated, taking into account the number of male subjects in relation to the female for all provinces.

\section{Results}

The cases diagnosed by HIV infection in adolescents in the country, in the period from 1987 to December 2018 (Table 1), corresponded to a total of 2090 cases, with male predominance (63.3\%), age 10 to 19 years (98.2\%) and white skin color $(56.7 \%)$. The incidence trend has been increasing both for the total and for each sex since 1995 (Figure 1). In Cuba, the HIV epidemic shows a slow growth rate. According to statistics on the situation of HIV / AIDS at the end of 2017 by automated registration of the Ministry of Public Health (MINSAP), there were a total of 28659 cases of HIV, of which 5048 died (17.6\%), died by AIDS 4535 and by other causes 513, people living with HIV 23611 (82.4\%) and male predominance (81\%). MSM represent $70 \%$ of the total cases diagnosed and $87 \%$ among those of the male sex Table 2. Adolescents accounted for $7 \%$ of cases (1955) in the 1987-2017 stage. (Cuba: Ministry of Public Health / National Directorate of Epidemiology. HIV / AIDS Statistics). The impact they have had on adolescent sex education, multiple educational programs at the school and community level, as well as by mass media such as the press, radio, television have contributed to greater protection against these infections. that could be the cause that the affectation in this population in Cuba is relatively lower and that the tendency of the epidemic, although it is ascending, as in the rest of the world, has not reached the magnitude that in other countries Table 3. 


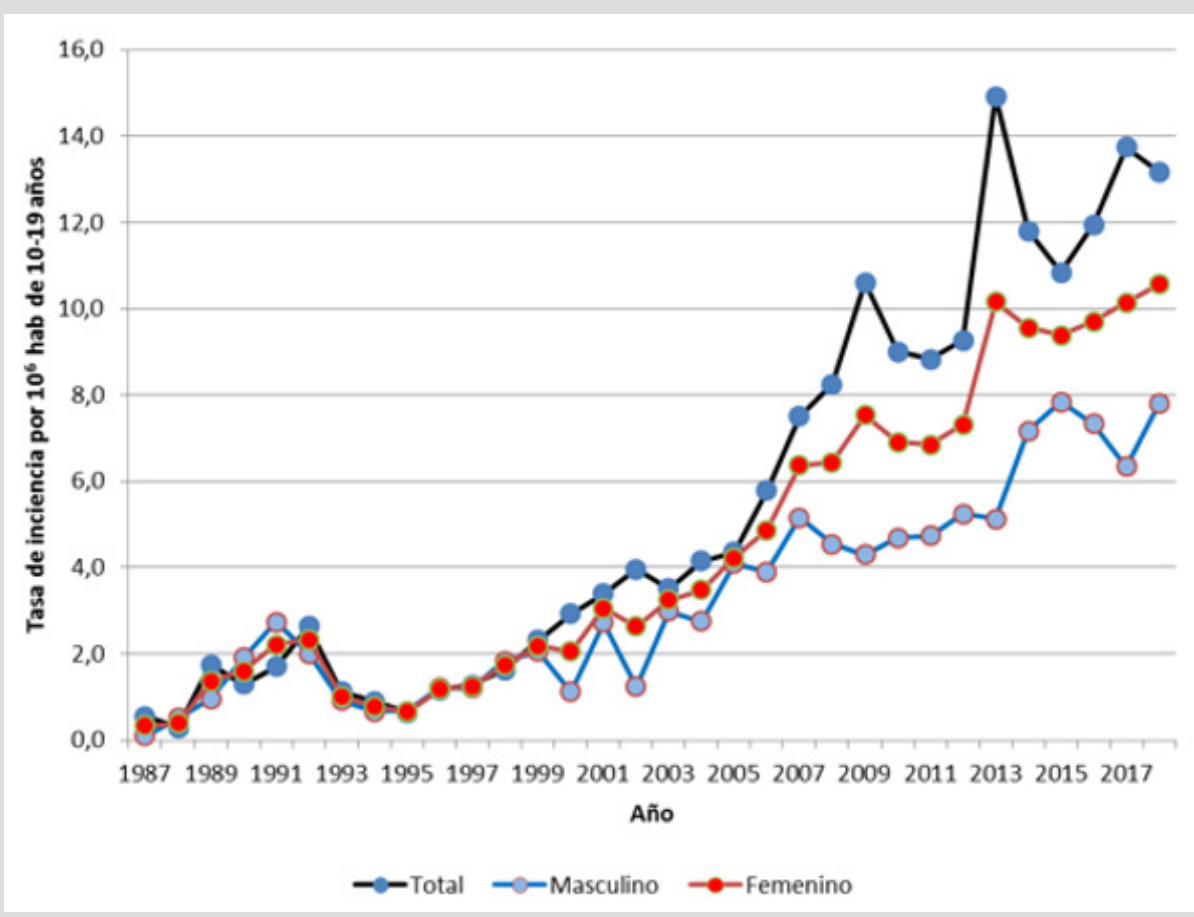

Figure 1: Trend of the diagnosis of IVH / AIDS in adolescents. Cuba, 1987-2018.

Table 1: Sociodemographic characteristics of cases diagnosed with HIV.

\begin{tabular}{|c|c|c|}
\hline \multicolumn{3}{|c|}{ Sociodemographic Characteristics } \\
\hline & No & $\%$ \\
\hline \multicolumn{3}{|c|}{ Sex } \\
\hline Female & 766 & 36,7 \\
\hline Male & 1324 & 63,3 \\
\hline \multicolumn{3}{|c|}{ Age } \\
\hline $10-14 \mathrm{a}$ & 38 & 1.8 \\
\hline $15-19$ a & 2052 & 98.2 \\
\hline \multicolumn{3}{|c|}{ Skin Color } \\
\hline White & 1186 & 56,7 \\
\hline Half Blood & 551 & 26,4 \\
\hline Black & 274 & 13,1 \\
\hline It does not report data & 79 & 3,8 \\
\hline Total & 2090 & 100,0 \\
\hline
\end{tabular}

Source: National Directorate of Epidemiology. MINSAP

Table 2: Distribution of HIV cases in adolescents by sex and province of diagnosis. Cuba 1987-2018.

\begin{tabular}{|c|c|c|c|c|c|c|c|}
\hline \multirow{2}{*}{ Province } & \multicolumn{2}{|c|}{ Female } & \multicolumn{2}{|c|}{ Male } & \multicolumn{2}{|c|}{ Total } & \multirow{2}{*}{$\begin{array}{l}\text { Masculinity } \\
\text { Index }\end{array}$} \\
\hline & No & $\%$ & No & $\%$ & No & $\%$ & \\
\hline Pinewood of the river & 29 & 3,8 & 76 & 5,7 & 105 & 5,0 & 262,1 \\
\hline Sagebrush & 25 & 3,3 & 51 & 3,9 & 76 & 3,6 & 204,0 \\
\hline Havana & 292 & 38,1 & 533 & 40,3 & 825 & 39,5 & 182,5 \\
\hline Mayabeque & 17 & 2,2 & 26 & 2,0 & 43 & 2,1 & 152,9 \\
\hline Massacres & 12 & 1,6 & 37 & 2,8 & 49 & 2,3 & 308,3 \\
\hline Villa Clara & 50 & 6,5 & 95 & 7,2 & 145 & 6,9 & 190,0 \\
\hline Hundred fires & 24 & 3,1 & 37 & 2,8 & 61 & 2,9 & 154,2 \\
\hline Sancti Spiritus & 14 & 1,8 & 24 & 1,8 & 38 & 1,8 & 171,4 \\
\hline Ciego de Avila & 29 & 3,8 & 51 & 3,9 & 80 & 3,8 & 175,9 \\
\hline
\end{tabular}




\begin{tabular}{|c|c|c|c|c|c|c|c|}
\hline Camaguey & 35 & 4,6 & 64 & 4,8 & 99 & 4,7 & 182,9 \\
\hline Las Tunas & 19 & 2,5 & 33 & 2,5 & 52 & 2,5 & 173,7 \\
\hline Holguin & 39 & 5,1 & 64 & 4,8 & 103 & 4,9 & 164,1 \\
\hline Granma & 41 & 5,4 & 77 & 5,8 & 118 & 5,6 & 187,8 \\
\hline Santiago de Cuba & 66 & 8,6 & 116 & 8,8 & 182 & 8,7 & 175,8 \\
\hline Guantanamo & 30 & 3,9 & 22 & 1,7 & 52 & 2,5 & 73,3 \\
\hline Isle of Youth & 44 & 5,7 & 18 & 1,4 & 62 & 3,0 & 40,9 \\
\hline Total & 766 & 36,7 & 1324 & 63,3 & 2090 & 100,0 & 172,8 \\
\hline
\end{tabular}

Source: National Directorate of Epidemiology. MINSAP

Table 3: Pathways of HIV transmission of adolescents under study. Cuba, 1987-December 2018.

\begin{tabular}{|c|c|c|}
\hline Transmission paths & No. & \% \\
\hline Bisexual & 153 & 7,3 \\
\hline Heterosexual & 916 & 43,8 \\
\hline Homosexual & 1021 & 48,9 \\
\hline Total & 2090 & 100,0 \\
\hline
\end{tabular}

Source: National Directorate of Epidemiology. MINSAP.

The National Strategic Plan for the prevention and Control of STI-HIV / AIDS (2014-2018) in Cuba establishes, among others, to improve the health status of the population and increase their satisfaction with the services provided, increase their reach ; as well as proposals for new actions to influence gaps identified in each area, thus favoring the access of the most affected population; updating the normative bases of the processes of prevention, attention, support, Tables 4-7 treatment, diagnosis and surveillance, which make up this plan. [7] The Family Physician and Nurse Program in which it is inserted into the Primary Health Care (PHC), the National Strategic Plan for the Prevention and Control of STIs and HIV / AIDS 2014 - 2018 and the National Program of Health for Differentiated Comprehensive Care in Adolescence will facilitate the achievement of superior results, encouraging rates to be even lower in Cuba and that the trend of the epidemic, although rising as in the rest of the world, does not reach the magnitude from other countries [7].
Table 4: Distribution of adolescents according to diagnosis. Cuba, 1987-2018.

\begin{tabular}{|c|c|c|}
\hline Diagnosis & No. & \% \\
\hline HIV & 1434 & 68,6 \\
\hline AIDS & 656 & 31,4 \\
\hline Total & 2090 & 100,0 \\
\hline
\end{tabular}

Source: National Directorate of Epidemiology. MINSAP.

Table 5: Distribution of HIV / AIDS cases in adolescents according to evolution. Cuba 1987-December 2018.

\begin{tabular}{|c|c|c|}
\hline State According to Condition & No. & \% \\
\hline Alive & 1764 & 84,4 \\
\hline AIDS deceased & 303 & 14,5 \\
\hline Died for another cause & 23 & 1,1 \\
\hline Total & 2090 & 100,0 \\
\hline
\end{tabular}

Source: National Directorate of Epidemiology. MINSAP.

Table 6: Adolescents according to state and provinces. Cuba, 1987-2018.

\begin{tabular}{|c|c|c|c|c|c|c|}
\hline \multirow{2}{*}{ Province } & \multicolumn{2}{|c|}{ Alive } & \multicolumn{2}{|c|}{ Died By AIDS } & \multicolumn{2}{|c|}{ Died by Another Cause } \\
\hline & No & $\%$ & No & $\%$ & No & $\%$ \\
\hline Pinewood of the river & 66 & 62,9 & 38 & 36,2 & 1 & 1,0 \\
\hline Sagebrush & 63 & 82,9 & 11 & 14,5 & 2 & 2,6 \\
\hline Havana & 707 & 85,7 & 113 & 13,7 & 5 & 0,6 \\
\hline Mayabeque & 38 & 88,4 & 4 & 9,3 & 1 & 2,3 \\
\hline Massacres & 42 & 85,7 & 7 & 14,3 & 0 & 0,0 \\
\hline Villa Clara & 101 & 69,7 & 39 & 26,9 & 5 & 3,4 \\
\hline Hundred fires & 52 & 85,2 & 8 & 13,1 & 1 & 1,6 \\
\hline Sancti Spiritus & 23 & 60,5 & 15 & 39,5 & 0 & 0,0 \\
\hline Ciego de Avila & 72 & 90,0 & 8 & 10,0 & 0 & 0,0 \\
\hline Camaguey & 92 & 92,9 & 6 & 6,1 & 1 & 1,0 \\
\hline Las Tunas & 49 & 94,2 & 2 & 3,8 & 1 & 1,9 \\
\hline Holguin & 90 & 87,4 & 11 & 10,7 & 2 & 1,9 \\
\hline
\end{tabular}




\begin{tabular}{|c|c|c|c|c|c|c|}
\hline Granma & 99 & 83,9 & 16 & 13,6 & 3 & 2,5 \\
\hline Santiago de Cuba & 165 & 90,7 & 16 & 8,8 & 0,5 & 0 \\
\hline Guantanamo & 48 & 92,3 & 4 & 7,7 & 0 & 0,0 \\
\hline Isle of Youth & 57 & 91,9 & 5 & 8,1 & 1 & 0,0 \\
\hline Total & 1764 & 84,4 & 303 & 14,5 & 23 & 1,1 \\
\hline
\end{tabular}

Table 7: Location of adolescents diagnosed with HIV. Cuba, 1987-2018.

\begin{tabular}{|c|c|c|}
\hline Location & No, & \% \\
\hline Ambulatory care & 1467 & 40,2 \\
\hline Foreign & 91 & 4,4 \\
\hline Passed away & 326 & 0,8 \\
\hline Denied attention & 16 & 0,2 \\
\hline Pending Attention & 5 & 2,7 \\
\hline Lost of Observation & 57 & 0,7 \\
\hline Sanatorium & 14 & 0,7 \\
\hline Penitentiary Sanatorium & 14 & 100,0 \\
\hline Total & 2090 & \\
\hline
\end{tabular}

Source: National Directorate of Epidemiology. MINSAP.

The Centers for Disease Control and Prevention (CDC), in their study of HIV among gay men and bisexuals [14], argue that gay and bisexual men are more severely affected by HIV and that in a study conducted in the United States From 2008 to 2010, gay, bisexual and other men who have sex with men (MSM) accounted for approximately $2 \%$ of the population and who are the group most severely affected by HIV. In 2010, gay and bisexual adolescent and young men (between 13 and 24 years old) accounted for $72 \%$ of new HIV infections in all persons aged 13 to 24 years and $30 \%$ of new infections in all gay and bisexual men. At the end of 2011, an estimated number of 500,022 people (57\%) living in the USA. UU. and had received an HIV diagnosis were gay and bisexual men, or gay and bisexual men [15]. It is common that at that age teenagers have sexual fantasies about their own sex and the other, feelings that may make them think that it is bisexual; but the fact that a person assumes this behavior will not determine their lifestyle or change their behavior. Society creates established patterns and often puts pressure on young people and adolescents by defining them as heterosexual or homosexual; however, they may not fit any of these categories $[16,20]$.

Villegas in his study found that among adolescents who reported having sex with other men, more than 54\% identified themselves as gay (gay), $23 \%$ as bisexual, and $23 \%$ as heterosexual [16]. In Cuba since the beginning of the HIV epidemic in 1986, sexual transmission has been recognized as the main source of spread. Of the total men diagnosed, about $86 \%$ are MSM (men who have relations with other men) and that these, as well as people who practice Transactional Sex (PPST) that is not more than people who practice sex in exchange for Some object, money or privilege. These people who practice transactional sex usually have relationships with a high number of sexual partners and therefore, are vulnerable to contracting sexually transmitted infections among them HIV, which is currently the most at risk, as well as the young people who constitute groups vulnerable to HIV infection [17]. Knowing the age of onset of sexual relations facilitates designing and directing in a focused manner the actions that aim to neutralize the risk of HIV transmission, in such a way, that adolescents are able to decide for themselves when to start their sexual relations, but accompanied by sufficient knowledge, skills and abilities, which allow you to opt for the self-care and care of your partner [18].

Cortés, in his study of HIV infection in adolescents. Cuba (19872014), found that within the total of those diagnosed, 1557 were adolescents, and the predominant sources of transmission were homo bisexual, unlike the current results, where homosexuality predominates [19]. Reports state that at least $28.0 \%$ of adolescents in South Africa are infected with HIV; 85.7\% more in relation to the $4 \%$ that affects men; according to a report from the official news agency SAPA. This stratospheric difference is attributed, according to the head of the Ministry of Health of South Africa, to the fact that older men sexually abuse and / or exploit adolescent girls, "it is clear that the girls were not having sex with young people of the same age, but with older men ", also referring to" They are destroying our children ", because adults abuse or seduce teenagers with gifts and promises to give them a better life, which their parents cannot give them [20]. In Cuba, the results of the Survey of Multiple Indicators by Clusters (MICS) carried out in 2014 by the Directorate of Medical Records and Health Statistics of the Ministry of Public Health, in collaboration with UNICEF, as part of the MICS global program, found within its main results in adolescent population aged 15 to 19 years, where 1039 (12\%) were female and 511 male, for 14\%, that $94 \%$ of females and $88 \%$ of males they were aware of a place to get tested; as well as they knew of their results, specifically those in the last year for females and males with $19 \%$ and $16 \%$; respectively [21]. 
Other strengths that are available in the interests of prevention are the different normative documents such as programs and resolutions that provide curricular output for all the teachings of the National Education System that includes, among other topics, Sexuality Education and STI prevention including HIV / AIDS from the gender, rights and sociocultural approaches [22-24]. Medical assistance and treatment coverage in Cuba is guaranteed and there is a strict control of people who live with HIV or are sick or sick with AIDS. There are different counseling services that include face-toface, anonymous, telephone and National Help Line; among other. In the National Strategic Plan for the Prevention and Control of STIs and HIV / AIDS 2014-2018, the normative bases of the processes of prevention, care, support, treatment, diagnosis and surveillance were updated, which are an integral part of the In the country there is also a counseling center for adolescents called "Center to + Teen Spaces" in Old Havana, the first of its kind in the country, focused on the age group of adolescents (12 to 18 years old) with Very good results since its creation.

\section{References}

1. (2018) WHO. Full WHO report on the AIDS virus (part 2). Data and numbers.

2. (2018) National Medical Science Information Center. National Medical Library HIV AIDS. World Statistics Factographic health.

3. (2015) World Health Organization. Self-analysis helps fight HIV in adolescents [Report].

4. Gómez S (2013) Two million teenagers worldwide live with HIV. Weather.

5. (2013) World Health Organization. Dealing with HIV in adolescence.

6. (2013) Infomed. National Medical Science Information Center, Ministry of Public Health: More than two million adolescents have HIV, WHO reveals.

7. (2013) Republic of Cuba. Ministry of Public Health. National Directorate of Epidemiology 2013 National Strategic Plan for the Prevention and Control of STIs and HIV / AIDS 20142018.

8. (2019) WHO. Development in adolescence. 2019.

9. Awuapara-Flores S, Valdivieso Vargas-Machuca M (2013) Biopsychosocial characteristics of the adolescent. OdontolPediatr 12: 119128.

\section{ISSN: 2574-1241}

DOI: 10.26717/BJSTR.2019.20.003517

Alba Cortés Alfaro. Biomed J Sci \& Tech Res

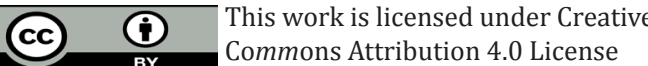

Submission Link: https://biomedres.us/submit-manuscript.php
10. (2006) Adolescence. General aspects and health care. Rev Cubana Med Gen Integr 22: 0-0.

11. Borrás Santisteban T (2014) Adolescence: definition, vulnerability and opportunity. CCM 18: 0-0.

12. (2012) UNICEF. Progress for children 2012: A report on teenagers. Join for childhood.

13. (2016) UNICEF-Cuba. World AIDS Day Internet. 2016.

14. (2015) CDC. HIV among gay men and bisexuals. Internet. 2015.

15. Villanuevas Ramírez A (2012) Bisexuality in adolescence. Why does bisexuality increase in children under 20 ?

16. Villegas L (2000) Young men who have relations with men. At risk of contracting HIV and other ET Advocates for youth.

17. (2013) Infomed. National Medical Science Information Center, Ministry of Public Health. STI / HIV / AIDS site. 2013. People who practice transactional sex.

18. (2013) Republic of Cuba. Population and Development Study Center. National Bureau of Statistics and Information. Survey on HIV / AIDS Infection Prevention Indicators, 2013. ONEI 2015.

19. Cortés Alfaro A (2015) HIV Infection in the Adolescence, Cuba, 1987 to December 2014: An Epidemiological Approach. J J Aller Immuno 3 (1): 021.

20. (2014) Infomed. National Medical Science Information Center, Ministry of Public Health (2014). South Africa reports alarming increase in HIV among adolescents.

21. (2014) UNICEF Multiple indicators survey by conglomerates. Cuba, 2014. Adolescents between 15 and 19 .

22. Torres Cueto MA, Roca Zayas AA, Caballero Delgado E, González Hernández A, López Gómez AB, et al. (2011) Sexuality education and its prevention of STIs and HIV / AIDS from the gender, rights and social approaches. Methodological orientations preschool, primary and special education. Ministry of Education; 2011.

23. (2012) Republic of Cuba. Ministry of Education. Ministerial Resolution: 139/2011. Sexuality Education Program with a focus on gender and sexual rights in the National Education System. Havana Cuba; Ministry of Education.

24. Torres Cueto MA, Carvajal Rodríguez C, Machado de Armas A, Sánchez Rodríguez M, González Figueredo A, et al. (2015) Director Program for health promotion and education in the National Education System. Havana: Editorial People and Education.

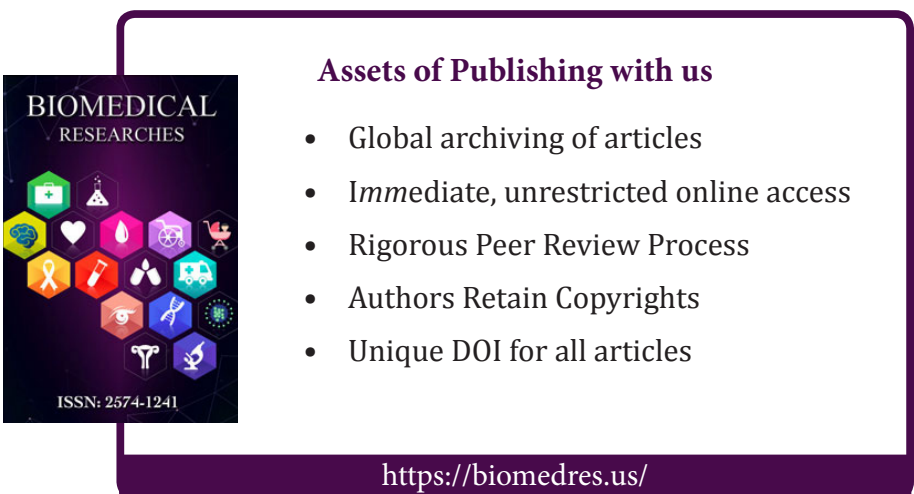

